Post-print. To appear in Language Policy, DOI: 10.1007/s10993-017-9451-5.

\title{
CLIL, unequal working conditions and neoliberal subjectivities in a state secondary school
}

\author{
Eva Codó \& Adriana Patiño-Santos
}

The introduction of English and other foreign languages as media of instruction, which is generally referred to as Content and Language Integrated Learning (CLIL), has transformed the teaching experiences of a large number of educators. Yet their daily struggles and personally ambivalent stances have hardly been examined. This paper addresses this overlooked area of CLIL practice by taking a critical sociolinguistic stance towards language-in-education policy. Drawing on an ethnographic case study, it analyses the on-the-ground implementation of PEP, a government initiative to foster the plurilingualisation of the Catalan education system, in a state secondary school near Barcelona. Through the situated analysis of policy makers', administrators', and educators' actions and discourses, the paper shows how the different groups of actors rationalise their engagement with the programme differently, while still aligning themselves with the official imagination of PEP, and constructing a collective ethos of commitment and hard work to improve the school's reputation. Three neoliberalised worker subject positions are identified: the entrepreneurial head teacher, who anticipates avenues for school transformation before they are put into place; the activised civil servants, who construct themselves as exemplary moral agents; and the maximally flexible temporary teachers, who live their participation in PEP with anxiety and a sense of burden, but are also aware of the many opportunities PEP offers. This paper contributes situated insights on CLIL implementation and addresses issues of power and inequality overlooked by the dominant paradigms in the field.

Keywords: plurilingualism; CLIL implementation; neoliberalisation of education; language policy; professional subjectivities; Catalan education system

\section{Introduction}

The introduction of English and other foreign/second languages as media of instruction has changed the learning experiences of a large number of children, adolescents and young adults around the world. It has also transformed the teaching experience of many educators, although their daily struggles and personally ambivalent stances have hardly been examined. It is true that some research on Content and Language Integrated 
Learning (CLIL) - the particular shape that English-medium instruction has adopted in Europe, and increasingly also in other parts of the world (Lin 2016; Turner 2013) - has put the focus on teacher experiences, but mostly to understand issues of professional legitimacy and identity (Morton 2016), as well as teacher beliefs (Bovellan 2014; Borg 2011; Hüttner et al. 2013). Other pieces of work have looked at policy measures to support educators, such as tuition-free working hours to create new CLIL-specific teaching materials or the institutional availability of specialist linguistic or methodological training (Banegas 2012; Pavón and Rubio 2010). Research so far has been largely oblivious to the overall working conditions of (mainly novice) CLIL teachers and the ways in which the introduction of English in compulsory levels of schooling hinges on the availability in the educational workplace of worker selves equipped to align the teaching profession with the conditions of flexibility, instability and fragmentation that define the contemporary work order (Gee et al. 1996).

This paper addresses this overlooked area of CLIL implementation by taking a critical sociolinguistic stance towards language-in-education policy and practice. We build on the tradition of ethnographic research in educational institutions being transformed under conditions of globalisation (Author 2014; Heller 2006; Pérez-Milans 2013; Rampton 2006). To do this, we adopt a case study approach to examine the on-theground implementation of the Plurilingual Experimentation Plan (PEP), ${ }^{1}$ a governmentsupported scheme for introducing CLIL in primary, secondary and vocational education in Catalonia (in the northeast of Spain) and how it unfolds in one specific school, which we shall call Pinetree Secondary. Pinetree is a state school located in a working class/lower middle class area close to Barcelona, the capital of Catalonia. Regular CLIL courses were first implemented in the school in the academic year 2015-16, during

\footnotetext{
${ }^{1}$ This is our translation of the Catalan Grup d'Experimentació per al Plurilingüisme (GEP).
} 
which we collected our empirical data, details of which are provided in section 4. Our goal is to understand the tensions that the implementation of such a programme created, how educators made sense of their engagement with it, and what forms of social inequality were engendered.

The paper is organised as follows. In the next section, a general overview is presented of relevant areas of research in CLIL. This is followed by a succinct explanation of the politico-economic perspective that frames our approach to plurilingual education. In section 3, some contextual information is provided on PEP, the government scheme framing the introduction of CLIL, as well as on the broader legal framework of education in Catalonia. Details on Pinetree Secondary School, the state school where we undertook our ethnography are to be found in section 4 . In section 5 , we begin with the analysis of the official discourse on the PEP scheme, its objectives, requirements and the process of school recruitment, to then move on to the ethnographic and discursive examination of how the different members of the PEP team at Pinetree understand, discuss and justify their involvement in the scheme. The conclusion will discuss the insights on CLIL policy that can be gained from the shift in analytical focus suggested in this paper.

\section{A critical sociolinguistic perspective on CLIL}

\subsection{Broad overview of research on CLIL}

CLIL has generally been defined as a "dual-focused educational approach in which an additional language is used for the learning and teaching of both content and language" (Coyle et al. 2010, p.1, italics in the original). Initially, it was presented as a distinctive European methodology, different from e.g. American content-based instruction (CBI) or Canadian immersion programmes; however, several authors have recently questioned such boundaries, arguing that different labels might merely be the product of different 
traditions rather than the result of dissimilar approaches to the integration of language and content (Lin 2016).

Pioneering CLIL promoters in Europe worked with the assumption that any additional language would be used as a medium of instruction. This was seen as a way of meeting the requirements of the European Union that all citizens be proficient in two foreign languages apart from their native one (European Commission 2003). However, over time the term CLIL has become almost exclusively associated with English-medium instruction (Cenoz et al. 2014). CLIL has rapidly spread across all educational levels and beyond European borders (see Turner 2013 for Australia, and Robertson and Adamson 2013 for Asia, where CLIL intersects with post-colonial and modernisation agendas) and has triggered innumerable research interests. Below is a succinct (though non-comprehensive) overview of CLIL research foci. We shall only review studies on CLIL implementation at compulsory levels of education (primary and secondary), as tertiary education is a distinct context in terms of student population, student interests and teaching pedagogies, and merits separate discussion.

A first group of CLIL studies has focused on how to define the scope of this approach as opposed to other programmes aimed at integrating language and content (e.g. Coyle 2007; Cenoz et al. 2014; Dalton-Puffer 2008; Ellis 2003). Some of these studies have focused on the use of L1 and of translanguaging practices as a distinctive trait of CLIL (Lin 2015). A second group has compared the implementation of CLIL in various educational and national settings, noting differences (e.g. Lorenzo et al. 2010) and similarities (e.g. Marsh 2002) between them. A further set has analysed the benefits and challenges of CLIL for the effective learning of a second language (e.g. Agustín-Llach and Canga Alonso 2016; Heras and Lasagabaster 2015; Muñoz 2007) and/or for learning content (Coyle 2007; Dalton-Puffer et al. 2010; Van de Craen et al. 2007). 
CLIL classroom practices have also received attention, as it is believed that the nature of teachers' and students' dialogical interactions impacts content access and language learning outcomes (Dalton-Puffer et al. 2010; Escobar and Evniskaya, 2014; Nikula 2010; Jakonen and Morton, 2013). A related line has centred on the perceptions of CLIL by different stakeholders (Borg 2011; Hüttner et al. 2013; Pladevall-Ballester 2015; Skinnari and Bovellan 2016), as well as on the effect of CLIL on students' motivation to learn English (Doiz et al. 2014). Finally, a significant group has concentrated on curricular issues and literacy skills at various educational levels (e.g. Llinares et al. 2012; Merisuo-Storm 2007). In the following section, we shall introduce our particular approach to CLIL education, which is novel in the field.

\subsection{An ethnographic and politico-economic perspective on CLIL}

As shown in the previous section, most CLIL research has been acritical. The existing critiques have sought (a) to identify aspects of implementation that deserve specific attention, such as the lack of specialised materials, insufficient CLIL training for content teachers, administrators' lack of awareness of teachers' needs and challenges, or lack of criteria to assess content and language in an integrated manner (Banegas 2012; Pavón and Rubio 2010); (b) to focus on any tensions that CLIL might engender between teachers of subject content and language teachers (Costa and Pladevall-Ballester, forthcoming) and (c) to deconstruct the multiple advantages attributed to CLIL in relation to language learning and quality of education (Bruton 2013).

Very few studies have brought to the fore the material conditions under which CLIL has been implemented, the social inequalities engendered by CLIL programmes and the ways in which CLIL impacts the daily lives of the institutions and agents implementing the programme. One exception is the ethnographic case study of a secondary school in Madrid, where a CLIL-oriented Spanish-English bilingual programme coexisted with a 
Spanish-intensive language programme for migrant students. Martín Rojo (2013) and Pérez-Milans and Patiño-Santos (2014) explore the multiple tensions and hierarchies among students and staff that the implementation of the bilingual CLIL programme generated. Relaño-Pastor (2015) analyses classroom data from the same programme to show how students resisted the elitist identities ascribed to them and foregrounded their working or lower middle class affiliations. This investigation also underlined the need to understand learning English as tied to local ways of "doing learning English" and students' affective histories. In the case of the school being studied, this meant not only engaging in fluid Spanish/English bilingualism, but also speaking English with a Spanish accent for social inclusion.

The perspective on CLIL that we adopt here is in line with these studies. It understands schools as social institutions, and applied linguistics as an interdisciplinary field (Rampton 1997). We argue that we need to understand CLIL programmes as complex undertakings involving a multiplicity of social actors with various (and sometimes conflicting) interests, enmeshed in networks of shifting economic, political and material conditions, and as constructing or reinforcing unequal power relations. This means viewing CLIL initiatives not just as pedagogical interventions but as processes that effect important changes in educators' work situations, career development opportunities, professional identities and personal lives. To do this, we must go beyond the narrow focus of most CLIL research on teaching practices and learning outcomes and into politico-economic processes. Block et al. (2012) argue that the interdisciplinary nature of applied linguistics advocated by Rampton (1997) has one "blind spot", which is precisely its lack of attention to political economy understood as combining "branches of economics and politics in order to understand how social institutions, their activities and capitalism influence each other in various ways" (p.2). This study 
purports to fill that research gap by questioning what "doing CLIL" means for nonlanguage teachers at this historical, political and economic moment in Catalonia.

This goal ties in nicely with current debates in the field of language policy and planning (LPP). According to Tollefson and Pérez-Milans (in press), what is needed in LPP is an epistemological approach that allows us "to reveal the specific links connecting trajectories of socially positioned actors with current social contexts." This is best achieved through critical ethnographies of language policies which bring together under one single research endeavour the "macro" concerns of state/institutional language policy analysis and the "micro" focus on the everyday contexts of policy engagement and interpretation.

In this paper, thus, we draw on the principles and practices of educational sociolinguistic ethnography (Codó and Patiño-Santos 2014; Heller 2006; Martín Rojo 2013; Pérez-Milans 2013), in order to provide an account of, on the one hand, how wider socio-economic and political orders shape local practices, relationships and identities displayed amongst the subjects and agents of educational practices; and, on the other, how these local practices, including discourses produced in the institution in which our study is situated, reproduce and, in some cases, justify such socio-economic orders. Our analysis combines field notes and participant observation with situated discursive data, more precisely, the professional narratives produced by the staff members of Pinetree Secondary School on their experiences as participants in the PEP scheme.

Our analysis will draw on recent work on the neoliberalising workplace and language therein (Urciuoli 2008; Urciuoli and LaDousa 2013). This line of research aims to dissect the ways in which workers are being re-imagined in contemporary work contexts. Workers are viewed as composites of skills that can be acquired, improved 
and commodified (i.e. monetised). Updating Foucault's notion of governmentality (1991), Fraser (2003) discusses how the new subject of globalised governmentality is the "active responsible agent" (p.168). The neoliberal citizen-worker has an entrepreneurial conceptualisation of him/herself, and is invested in self-training and skills development as the path to personal transformation and self-actualisation. The urge to acquire new skills, to self-develop professionally, operates as the neoliberal technology of self. Urciuoli and LaDousa (2013) discuss the link between new subject positions and shifting institutional orders. As we shall see in the data analysis, these new subject positions, are "emergent, unsettled, and sometimes unsettling" (p.179). In this vein, Gao and Park (2015) show that becoming proficient in English has become a contemporary technology of self, linked to the enactment of worker selves orientated towards moralised neoliberal values. Taking steps to develop one's language competence - through, for example, geographical mobility - indexes one's flexible disposition, willingness to self-improve and superior moral stance, "a professional morality" in their own words (p.87). This, as we shall see, is evident in our data. We shall now turn to a brief explanation of the multiple contextual elements framing the design and implementation of PEP, the language programme underway at Pinetree.

\section{The educational, legal and language policy context}

Initiatives to introduce English as a medium of instruction through CLIL began in Catalonia as early as the 1990s (see Lorenzo Galés and Piquer Vives 2013 for a fairly comprehensive historical overview). As education policy is highly decentralised in Spain, language-in-education is largely in the hands of regional administrative bodies. For this reason, there are significant differences in the nature and scope of the various bilingual or plurilingual programmes put into place across the Spanish state (see e.g. 
Bros Pérez 2015, for a succinct review of differences in CLIL implementation in three Catalan-speaking regions).

The introduction of English as a vehicular language in Catalonia has added a further layer of complexity to what was already a highly complex reality. The declared language education goals of the Catalan education system are to make all students competent in the two co-official languages, i.e. the state language, Spanish, and Catalan, the local, historically minoritised but socially fairly prestigious language, with the objectives of ensuring equal opportunities and enhancing social cohesion.

Aware of the need to raise levels of English competence among children and adolescents in the context of a globalised and tertiarised economy, a number of policy schemes have been put into place by the Catalan government to popularise CLIL at primary, secondary and post-secondary levels. PEP belongs to what we might call the "third wave" of CLIL-support initiatives. First wave programmes were defined by their pilot nature (1999-2005); the second wave aimed to consolidate CLIL as a language learning methodology (2005-2012); and the third wave aims to extend CLIL more widely. One key difference between first/second and third wave plans is the procedure for school participation. Whereas in the former, schools applied within open call schemes, in the latter they are selected by government officials. This is a crucial contextual element for understanding policy implementation at Pinetree Secondary School, as we shall see. In spite of direct nomination, there is relative leeway for schools to refuse participation. This is because, unlike in other regions (Bros Pérez, 2015), the Catalan approach to CLIL has tried to avoid the top-down imposition of language policy at the expense of the continuity and the stability of programmes (Navés and Victori 2010). 
PEP is basically a training scheme for head teachers and CLIL practitioners-to-be, which started in 2013-2014. It extends over two academic years in the form of four 4hour sessions per year. In the first year, general methodological training is provided, focusing on how to implement project work and task-based learning. The second year is more directly centred on CLIL. Teachers are asked to start doing CLIL. They have to design and implement a CLIL project for which they receive feedback from both peers and trainers in the final session. No language training is provided, as teachers are expected to have a B2 level of English already. PEP-trained teachers are expected to become trainers in their own schools, helping and encouraging colleagues to implement CLIL. Eventually, English (or French) should be consolidated as a vehicular language and included in the school's linguistic project.

The broad language policy initiative framing PEP is the "Framework for Plurilingualism", developed by the Catalan government for the period 2013-2016. Its declared aims are to improve the quality of Catalan education and contribute to developing a unique linguistic model for the Catalan education system which fosters plurilingual competencies without undermining the centrality of Catalan. The "Framework for Plurilingualism" is presented as linking up with supranational agendas, more specifically, the Europe 2020 objectives of easing mobility on a continental level and enhancing European workforce employability and competitiveness, in the pursuit of which foreign languages are believed to be instrumental (Beadle et al. 2015).

More broadly, a key contextual element that needs mentioning here is the LEC, the Catalan Education Law, passed in 2009, as it bears heavily on the employment conditions of some of the teachers involved in PEP at Pinetree Secondary. The LEC defines the regulatory framework of state-funded education in Catalonia. One of the changes that the LEC has introduced with regard to previous laws is the granting of 
greater autonomy to schools in defining their own educational and organisational projects, and intervening (to a certain extent) in the recruitment of new teachers and the renewal of contracts for temporary ones. LEC has been said to introduce the logic of the market into the Catalan education system by intensifying elements of competition among schools. CLIL schemes are amongst the most popular options employed by schools to seek distinction (Lorenzo Galés and Piquer Vives 2013).

\section{The secondary school}

From September 2015 to July 2016 we investigated ${ }^{2}$ the on-the-ground implementation of PEP at Pinetree Secondary School. ${ }^{3}$ We employed ethnographic methods of data collection which involved intensive engagement in the field: the collection of spontaneous narratives, as well as previously arranged semi-structured individual and focus group interviews with the teaching staff; observation of classes, both English language classes and content courses taught in English at different educational levels (from 12 to 16-year olds) and covering a variety of subjects (PE, technology, lab research and social sciences) as well as audio-recording of one CLIL course. A significant number of visual and textual documents were also gathered and relevant institutional events (such as an Open Day information session for prospective parents) were attended. Although fieldwork is still ongoing, the analysis presented here is based on the following sets of data: ethnographic field notes from 26 visits to the school, an interview with 1 (of 3) senior members of the Department of Education in charge of the design and implementation of the PEP programme; a focus group with the PEP teachers, the school head and the head of the English department and 5 semi-structured

\footnotetext{
${ }^{2}$ These data were gathered for the APINGLO-Cat Project (2015-2017), funded by the Spanish Ministry of Economy and Competitiveness (ref. FFI2014-54179-C2-1-P). We would like to thank Iris Milián for her help with data transcription.

${ }^{3}$ For ethical reasons, the name of the school is a pseudonym, as are the names of all the other participants.
} 
individual interviews with the content teachers who were participating in the programme.

Pinetree Secondary School is a state-funded school located in the centre of a working class/lower middle class area on the outskirts of Barcelona. The school offers compulsory secondary education and baccalaureate, but no vocational training schemes. The language education programme on offer is comparable with that of most state secondary schools in Catalonia: Catalan is the preferred vehicular language, Spanish is taught as a subject, English is the compulsory foreign language and French is optional. In 2013-14 a pilot scheme to teach an optional course in English was started and continued with the partial teaching in English of a compulsory course in 2014-15. That same year, four teachers began attending the two-year PEP training scheme - previous to their starting to teach their content courses totally or partially in English. In 2015-16 PEP was begun. Five teachers ${ }^{4}$ (out of some 50 staff members) started to teach their content courses in English following a CLIL methodology. At the time of data collection, Pinetree Secondary School was the only one of five state schools in the city to provide CLIL education.

The school enjoys a good academic reputation in the local education market as proven by growing enrolment rates. This has not always been the case, and a fairly "dark", i.e. non-academic and socially conflictive period for the school (some 10 years ago) is still vividly remembered by veteran teachers and some students and families. The new managerial team (2013-2017) has consolidated the academic profile of the school. "Quality teaching in the centre of the city" is the motto announced on the school webpage. Various initiatives connected to English (and to a lesser extent French), including PEP, have formed the basis of the school's commitment to quality education.

\footnotetext{
${ }^{4}$ The five CLIL teachers belong to the "PEP team", although only four of them attended the training.
} 


\section{Data analysis}

To understand the situated evolution of PEP, it is important to analyse first how the official discourse defines what PEP is, what kinds of schools it is designed for and what kind of engagement it requires from schools, head teachers and educators. The PEP objectives, criteria for school selection and requirements for programme implementation are contained in the Catalan Department of Education's Resolution of $8^{\text {th }}$ April $2016 .^{5}$ According to this document, the aim of PEP is to "foster the development of interdisciplinary and transversal projects in order to activate the students' plurilingualism in at least three languages" (p.1). No specific mention is made of CLIL, but rather one of "actions to teach curricular content and other education activities in one of the foreign languages of the curriculum". 6 This gives a lot of freedom to schools to decide how to implement PEP (no minimum requirements are established in this official document, though in fact there was a minim of one action - a course, a didactic unit, etc. - for each of the 4 grades of compulsory secondary education). All statefunded schools are, in principle, eligible to participate, but selection will be made by the local administration. The document includes a section on requirements and obligations. Candidate schools must submit a two-year plan containing envisaged PEP actions. This plan has to be approved in a staff meeting (claustre) and incorporated into the schools' pedagogical and language project. Schools must also ensure the human resource infrastructure for the organisation of the programme by involving the managerial staff, two to three content teachers to be trained as PEP teachers, but also the availability of regular meeting times for the "PEP team". Impact measures are also contemplated, such

\footnotetext{
${ }^{5}$ This document is available from: http://educacio.gencat.cat/documents/PC/ProjectesEducatius/Resolucio_GEP_2016.pdf (Retrieved 6th July 2017).

${ }^{6}$ Our translation from Catalan.
} 
as publicising the programme on the school web page and the publication of the actions, didactic units and materials developed under this framework.

As part of our fieldwork, we interviewed Àngels, the senior official coordinating PEP in the regional government. One of the things we wanted to find out more about was the criteria for choosing schools. The following extract contains crucial information on this, shedding light on situated policy implementation (transcription conventions are provided in the Appendix).

\section{Excerpt 1: "Schools with the capacity to progress",}

1. ANG: how::/ are [the schools] selected/ well the territorial services are asked to look for schools/ following this this this this this \requirement\}

2. EVA: which are::/ ((laughs))

3. ANG: well::\(.) the criteria have been evolving as well

4. $E V A:=a h[O K \backslash$

5. ANG: [but $\backslash$ (.) the first year it was/ (.) schools / u:::m\(.) that were average:/ neither excellent schools $\backslash$ because they are already doing CLIL/ they are already doing things/ because they are already doing them\

6. EVA: OK\

7. ANG: =nor schools that:: \have lots of problems/ because that would be difficult/ (.) schools with the capacity to:/ (.) to progress:/ right/

8. EVA: $m:$ OK\

9. ANG: e::\

10. EVA: in other words \exactly the school/ that we are looking at \it's it's exactly this picture $\backslash$ (.) yes $\backslash$

11. ANG: e:::m\motiva::ted/ willingly to do it::\ with a managerial staff who::/ want to support the project::/ who are willing to a give them::\(.) a bit of time to organise things::/(.) with someone who::\(.): who wants to mount a (team) effort:::/ and so on\

12. EVA: $\mathrm{mhm} \backslash$

13. ANG: with staff who:::\ are not English teachers/ but who have a good enough level of English/ to \jump in at the deep end to do that $\backslash$ (.) these were the criteria \(.) so the territorial services/ (.) sent us their proposals\

14. EVA: $m h m \backslash() O. K \backslash$

15. ANG: =and they::\(.) proposed some schools

In this extract, Àngels specifies the organisational and "attitudinal" requirements that PEP schools should meet. In turn 7 she describes eligible schools as "schools with the capacity to progress", which she defines as halfway between "excellent schools" and

\footnotetext{
${ }^{7}$ For reasons of space we are only providing English translations of the original narrative data in Catalan.
} 
those "with many problems". This description of target schools indexes, in fact, the central (although not explicitly stated) mission of PEP, namely to extend CLIL practice beyond the group of early adopter or innovation-focused schools. From that turn on, we can reconstruct how the category "schools with the capacity to progress" is envisioned by language policy officials. Motivation and willingness to "do PEP", as well as a supportive managerial team, are at the core of contextual requirements. Such attitudinal traits (which, we will later assert, constitute Pinetree's collective ethos) are embodied by teachers and school administrators. In what follows we will analyse, ethnographically and discursively, three worker subject types that are both the condition for and the outcome of PEP implementation: the entrepreneurial self, enacted by Pepa, the head teacher, discussed in 5.1; the activised civil servant, embodied by Xavi and Núria, contained in 5.2, and the maximally flexible self, represented by Juan and Anna, analysed in 5.3. These three subject types respond to the unequal positioning in the school organisation of each teacher group and their different contractual situations. ${ }^{8} \mathrm{We}$ will discuss the ways in which each group participates and rationalises their involvement in the PEP programme by bringing to the fore their anxieties, aspirations and ways of defining the situation. The three selves represent the complex and unequal symbolic and material conditions under which this local government plan is delivered.

\subsection{Pepa, the entrepreneur, leading a visionary team}

As is the case in other Catalan schools, mainly from peripheral areas, Pepa, the current head of Pinetree, found in PEP an opportunity to improve the school's reputation, and the academic performance of its students. Supported by her 20 -year trajectory as a

\footnotetext{
${ }^{8}$ In the Catalan/Spanish system, permanent teachers are government employees with positions for life (funcionaris). Access to these positions requires passing an official examination (oposicions). Because of the emic relevance of the term funcionaris (literally: civil servants), we will refer to teachers in this category as civil servants throughout this paper. The teachers with non-permanent positions are called interins in Catalan, and we will refer to them as non-permanent or temporary teachers. Interins are typically appointed to a different school each year.
} 
school teacher, she is a respected leader. A few years ago, she decided to take a six-year leave during which she worked in the private business sector. This seems to have had some influence on the way she manages the school.

She is a very positive and enthusiastic character who supports all her teachers' initiatives. "I always say yes (to any proposal)" is an identity trait of hers that she keeps repeating to whoever cares to listen. Another aspect that she likes foregrounding is how much she (and the educators at Pinetree) work, especially during evenings or weekends and in July, when everybody else is on holiday. During our ethnography, we observed how the teachers were continually motivated to propose or participate in projects, innovative schemes, training opportunities, out-of-school trips and visits, and in general any activities that involved themselves and the students in extracurricular activities where team work and social skills were fostered. In this vein, Pepa was one of the most enthusiastic proponents of PEP. In her discourse Pepa aligns with and displays the school's "capacity to progress" that Àngels made relevant as the basic requirement for becoming a PEP school.

Whenever our research team discussed the origins of PEP at Pinetree with Pepa, she would recall her pioneering decision to encourage some content teachers (more specifically Anna, to whom we will refer later) to start teaching an optional course in English back in 2013, before PEP had been launched, and to have supported other initiatives related to the promotion of English, such as inviting ERASMUS students to give talks in the school. In telling and retelling these avant la lettre initiatives, Pepa enacts an entrepreneurial and even "visionary" self who anticipates avenues for school transformation before they are put in place. Excerpt 2 allows us to complete the foundational narrative re-created by Pepa where, besides emphasising collective agency, 
she puts a great deal of discursive effort into backgrounding vertical decision-making and the potential tensions generated by PEP.

\section{Excerpt 2: "Not French but English"}

54. PEP: and it seemed to us that starting at school and and in the first year having music in French was like like a way to force it a bit \right/ but we said mind you the English [scheme we could do]/ ((laughs)) we think we are (.) talking about people (.) who had an acceptable level of English so we could do it $\backslash$ so then we talked to the staff/ Anna: and Eduard aaa: Núria and Juan e:mmm signed up/ before that/ Anna was already doing things in English with the first years/ they started on the plurilingual idea saying well/ start do::ing the optional PE class: of basketball in English/ which is easy and so on

55. EVA: $\mathrm{mhm}$

56. PEP: because the kids had more occasions when they could speak or hear English and for them to express themselves that way / she ran PE for the second years last year / right/ but all that wasn't part of a project/ [but rather it was:

57. EVA: [not part a school project/

58. PEP: it was it was the plurilingual project right- $\backslash$ it wasn't the PEP project $\backslash$

59. PEP: [so it was last year when we accepted the PEP

In this extract, Pepa constructs the suitability of the Pinetree teaching staff for PEP. She makes the staff's agency relevant by presenting their active role as decision makers. This is signalled in turn 54 through key actions, such as refusing the suggestion of PEP representatives to implement the programme in French, as none of the primary schools where Pinetree students come from has a French language programme. This decision indexes the axiological values of committed teachers who do not hesitate to defend their students' interests. Pepa emphasises how they strictly followed the requirement that PEP be a schoolwide endeavour to be discussed and approved at the staff meeting. To foster the idea of horizontality and consensus, Pepa uses the Catalan verb "apuntar" (literally sign up for) to characterise the process of teacher selection for PEP (turn 54). In her discursive reconstruction, the four teachers voluntarily decided to join PEP, ${ }^{9}$ but this version of the foundational narrative is challenged by some of the educators, as we shall see later. It is interesting to observe how Pepa backgrounds the way in which Anna

\footnotetext{
${ }^{9}$ Note that Pepa does not mention the fifth teacher, Jordi, whose engagement was "taken for granted" given his second language proficiency and his being part of the school's managerial team. Having a member of the managerial team among the PEP members was also an official requirement for PEP participation.
} 
came to teach her optional course in English ("Anna was already doing things in English"), leaving it to the listener to infer that it was Anna's decision. Pepa's rationale for the decision to introduce English as a vehicular language appears in turn 56 "because the kids had more occasions when they could speak or hear English and for them to express themselves that way", which highlights her and the whole team's commitment to catering for their students' needs.

To summarise, Pepa makes relevant a collective self of committed and proactive educators led by an enthusiastic head teacher, who are all for giving students the means to better their futures, and they have the linguistic ability and the team ethos (willingness, motivation, hard work and readiness to engage in teamwork) demanded by the policy makers. The team ethos produced by Pepa is retold (re-appropriated) by the teachers according to their own material circumstances, foregrounding tensions between professional duty and the material conditions framing PEP.

\subsection{Jordi and Núria, the "activised" civil servants}

Jordi and Núria represent the voices of those civil servants who find in PEP the opportunity to contest the public imagining of state employees as lazy, passive and comfortable in their stable situations. Jordi, a permanent technology teacher, is a member of the school's managerial team that promoted the plurilingual shift in 2013 , before PEP arrived. Núria, in turn, is a permanent science teacher who decided to start teaching in English before it was required by PEP by introducing some activities in her elective Lab Research course. Excerpt 3 illustrates the ways in which Jordi and Núria co-construct their exceptionally activised civil servant selves.

\section{Excerpt 3: "The only civil servant there was me"}

313. JOR: one second $\backslash($ (.) I (.) when I became a (permanent) secondary school teacher / I went to London to do a three-week course/ (.) [right/ 
314. PEP:

[right/

315. JOR: and the only civil servant there/ was mel

316. NUR: me too

317. JOR: yes but she was in another ( )

318. JOR: there were people there who hadn't even been employed for one year\

In this extract, Jordi enacts the "opportunity discourse" when in turn 313 he brings to the communicative scene a small story in which he describes himself as taking advantage of government-sponsored language training at his earliest opportunity. Jordi's going to London is presented as happening immediately after his having become a permanent teacher, which we know ethnographically was actually not the case, since he took the course two years after he had signed a permanent position. Jordi's discursive goal is achieved, since his story manages to create a sense of immediacy that indexes his entrepreneurial subjectivity in line with the team ethos that Pepa wants to foster in the school and to which PEP is instrumental. This is reinforced in turn 315, when Jordi claims that "the only civil servant there was me" to which Núria, the science teacher, retorts by reminding him that she was there too. So, in the evaluation, Núria and Jordi jointly recreate the collective moral ethos of the school by presenting themselves as different and even rare among the category of funcionaris (civil servant teachers). In line with Gao and Park (2015), developing one's English competence is a key action indexing self-responsibility and professional worth. Jordi, in particular, manages to present himself as an exemplary moral agent, who, despite his comfortable professional situation, seizes every chance for professional development. This invests him with the moral authority to implicitly judge those who do not do so, as observed in turn 315 .

In other parts of the focus group, discourses of individual motivation and professional and personal challenge were also drawn upon to explain teachers' involvement in PEP. Eduard, the third funcionari involved in PEP, even used the word "reactivating myself" as a justification, clearly echoing activation discourses typical of neoliberal policy 
(Garrido and Codó 2017). What we see is a complete alignment between PEP schools in the official imagination, the foundational narrative constructed by Pepa and the subjectivities constructed by the permanent teachers involved in the scheme. Let us now turn to the cases of the two non-permanent CLIL teachers by examining in detail the narrative produced by one of them, Juan.

\subsection{Juan and Anna, the "masochistic" non-permanent teachers}

More difficult material conditions are evoked in Juan and Anna's discourses and actions. Both represent the group of non-permanent teachers who are "asked" by the institution to participate in PEP. Juan, the technology teacher holds a BSc in maths but was offered a temporary position at Pinetree Secondary School as a technology teacher. He has been in the school for two years. Like Anna, the PE teacher, he was requested to participate in PEP by the head teacher, Pepa. While Anna is very explicit about the fact that she could not ignore Pepa's request if she wanted to continue working in the same school, where she has been for eleven years, Juan constructs a more nuanced discourse, which blends elements of personal opportunity, interest and motivation - in alignment with his permanent colleagues -, a moral commitment to what he sees as quality state education in a working class/lower middle class neighbourhood and, like Anna, his desire to keep his post at Pinetree, where he is professionally satisfied.

Juan's discourse is more student-orientated than the discourse of some of the permanent teaching staff, who, as we saw above, focused more on personal rewards. For him, PEP means "a benefit both for the school and the students" and a personal opportunity to reconnect with the language. Yet, all this is at a high personal cost, as he discusses in the interview with Eva.

\section{Excerpt 5: "PEP is for masochists"}


598. EVA: OK\ well \I had a question (...) (.) does it help or hinder you / well it hinders you / I guess/ like in terms of the number of hours that you need to inve::st in it right/

599. JUA: yes $\backslash$ (.) for me and my home $\backslash$

600. ((laughs))

601. EVA: to your family!

602. JUA: well \(.) yes (like everything \) that's how it goe::s (.) there are weekends that you're shut away doing work / (.) forever / [and that produces more work \(.) and ( ) being

603. EVA: [ye:s\

with the gi::rls \and my wife:\

604. EVA: there's the work produced by the subject / and the work produced by the PEP $\backslash$ (.) they are two jo::bs\

605. JUA: well I mean that PEP stuff \ making us prepa::re $\backslash$ (.) a:: whole \topic / (.) that ( ) that I mean a topic is not just a couple of sessions $\backslash$ (.) if they ask you \[

(...)

1133. [...] they are \still \(.) many more hours of preparation/ (.) at home $\mathrm{i}:: \backslash$ (.) it gets to a point/ that you have a family $\backslash$ you have a life $\backslash$ (.) and all that $($ ) also- $\backslash$ the work that you do at school / o::r (.) at a language school or (...) I mean I I/ I was telling (her) \ every day / (.) I go to bed a::t half one two in the morning.

1134. EVA: but that's awful!

(...)

1141. EVA: and the MARKING/ (.) and all that/

1142. JUA: yes yes \I mean:: \\(.) (you leave) the schoo:I \at two thirty $\backslash$ (.) you get home at three three thirty \(..) you keep ( ) who's gonna cook \(.) ( ) cook\(.) my wife has another job\। do the cooking $\backslash(. .$.$) ( ) so you get down to it at five in the afternoon \backslash$ (.) you go to pick up the kids \and I want to spend time with my girls $\backslash$ (...) [I want to be with them \then it's half past eight / (.) dinner/ (.) off to bed $\backslash$ (.) so from ten/ (.) work::/ starts $\backslash$ (.) preparing cla::sses / marking exa::ms/ (.) at the same time \ (.) I also\go to the:: \ I go to a language school \to (...) the official language school $\backslash$ (.) they are afternoons that you take out $\backslash$ (.) when/ you do training courses/ you have one of them in the afternoon $\backslash($.$) and on top of that everything$ tha:t I'm doing for the PEP\ (.) a:: and all that's necessary for the technology [courses] $\backslash$ which are projects/ (.) it's not like maths where you present a topic/ a you say ok\ tomorrow I need to expla:in/ this bit here \no\no\ there you need to do \(.) you need to prepare / work and so on $\backslash$ (.) there are lots of (...) things $\backslash$ (.) lots $\backslash$ now we have a three D printer (...)

1153: EVA: so / you have a three:: D printer/

1154. JUA: ye::s\ (.) well if you want [I can show you it] later (.): and I am in charge o::f o:f/]

1155. EVA: $\quad[a:: h \backslash($.$) of making it work working (.)$

1156. JUA: I need to prepare thi::ngs/ to keep practising / [(.) I am doing (...) lots of things $\backslash($.$) there$ is no time $\backslash$ and if you want to dedicate time to your family the::n\

In turn 599, as a response to Eva's question about a detrimental aspect of PEP that Juan himself had brought up previously, Juan elucidates: "for me and for my home". In turn 605, he focuses on the additional work that the PEP training signifies. Juan then summarises his busy life as a non-permanent teacher to get to the critical point of his experience when we claims he goes to bed "a::t half one two in the morning" every night (turn 1133). In turn 1142 he offers more evidence of his difficult situation by explaining in detail his daily afternoon schedule and spelling out the many job-related activities he engages in, such as taking English classes in order to obtain an official B2 
certification $^{10}$ and periodically enrolling in teacher training seminars, apart from his setting up of technology projects (we must remember that he is a mathematician, not an engineer, and that this is the first year in which he has taught technology courses). In turn 1155 he summarises his points through an implicit assessment: "there is not much time $\backslash$ and if you want to dedicate time to your family the:nl”. The vowel lengthening and the suspense tone indicate that there is an implicit negative evaluation of the situation that cannot be avoided. So stressful is the situation for Juan that later on, after the interview had finished and Eva was on her way to visit the technology lab with him to see the new 3D printer he mentions in the excerpt, Juan started talking about PEP again and summarised his personal stance as "if you're interí (non-permanent), PEP is for masochists" (field notes, 22/01/2016). His readiness to make the personal sacrifices that being involved in PEP entails is encapsulated in his alignment with Pepa's argument in the focus group discussion (excerpt below).

\section{Excerpt 6: Quality state teaching as a moral duty}

388. PEPA: [...] it's like at the level of the public image in [the city]/ like/ having a secondary school where a number of classes/ fifty percent \twenty percent \or ten percent are taught in English \ on top of the English classes/ I think it gives it a good reputation/ if I had a kid I'd put [him in that school]

389. JUA:

local STATE school ((said slowly and with emphasis))

In turn 389 Juan's contribution adds concerns of class equality to Pepa's discourse about the advantages of PEP. That is, for Juan the important thing is that they are working in the interests of social justice, enabling Pinetree students (most of whom are of working or lower middle class backgrounds) to access skills, such as competence in English, that have long been considered the prerogative of the upper-middle classes in

\footnotetext{
${ }^{10}$ Given the limited availability of content teachers with an accredited B2 level, it is currently possible to occupy one such position in Catalonia without an official foreign language certification. This moratorium will expire on June 30th, 2019.
} 
Catalonia. So, Juan is caught in a tension between a moral commitment to quality education, his need for professional stability and the demands of a system which exploits the insecurity of non-permanent teachers to carry out projects such as PEP.

\section{Discussion and conclusions}

A great deal of current research has focused on the contextual practicalities affecting learning in CLIL contexts. However, very few studies have tried to link what happens in the classroom with wider socioeconomic and political processes. The ethnographic examination of how CLIL is being "done" in Catalonia, that is, why certain schools come to offer CLIL and why they manage to get certain teachers (and not others) on board has allowed us to present a larger picture of CLIL implementation. It has enabled us to explore some of the situated challenges, tensions and decisions that policy makers, teachers and administrators, as the social actors in charge of implementing new language policies, make. The analysis of the data gathered at Pinetree Secondary during the 2015-16 academic year has allowed us to reconstruct the different stances taken by the different groups of social actors according to their distinct institutional roles, circumstances and personal/professional agendas. With this new approach to CLIL we aim to contribute to current research by addressing key issues to do with power inequalities and teachers' working conditions that have not been taken into account under the dominant research paradigms in the field.

Regarding policies, our aim has not been specifically to analyse PEP, its effectiveness or implementation process, but to show the ways in which policy is practised. We believe that "practised policy" must be understood as inextricable from the particular political, cultural, ideological and socio-economic histories of each actor and social context (Pérez-Milans 2015). We have shown how the introduction of a marketplace 
logic into the Catalan public education system, in the form of measures of greater school autonomy (encouraged by the new education law), leads schools' heads to search for elements of distinction that set their schools apart from similar institutions in a highly competitive educational arena. Given the globalisation and linguicisation (Pujolar, 2007) of the economy, most of these "innovative" actions are geared towards the intensification of plurilingual language-in-education policies that mainly (though not exclusively) prioritise English. ${ }^{11}$ The insistence on foreign languages taps into Catalan parents' anxieties about their children's future employability in national and global markets. This linguistic frenzy, we argue, is also generationally tied to parents' own failure to achieve fluency in English, often attributed to the formal approach to language education prevalent in the Catalan/Spanish education system until recently.

The adoption of English as one of the assets to compete in this education market represents, for schools located on the periphery and with poor reputations, the possibility of attracting more academically-orientated students. As reported in other regions of the Spanish state, such as Madrid (Pérez-Milans and Patiño-Santos 2014, Relaño-Pastor 2014) and current research in Castilla-La Mancha (Relaño-Pastor 2018, becoming a bilingual or plurilingual school can transform the social image of secondary education institutions which have faced truancy and dropping-out. The embracing of English as an asset for the school normally encourages the managerial staff to foster and support initiatives related to bi/plurilingualism, as we have shown in the case of Pinetree. Since the PEP scheme is still in its early stages, we can only observe provisional results to fulfil the managerial staff's expectations. Thus, for example, some months ago, the head teacher showed us, very proudly, how the results for English of

\footnotetext{
${ }^{11}$ Batxibac, a scheme to foster the learning of French, is also very popular among Catalan families and schools. It is a bilingual and bicultural programme allowing students to obtain both the Spanish and the French baccalaureate degrees.
} 
students finishing compulsory secondary education have improved with respect to previous years. For teachers, in turn, English is the new skill required for employment or professional stability. As we have seen, English proficiency allows pre-service content teachers the possibility of accessing a teaching position more easily or have relatively more stable employment.

At Pinetree Secondary PEP is made possible thanks to the dedication of a group of teachers who align themselves with the circulating discourses and practices of distinction that help lend their school prestige in the area. However, the ways in which the teachers participate in the programme are diverse and unequal, given their different employment circumstances. Such conditions give rise to an internal stratification of the workforce and draw on a set of subjectivities aligned with a neoliberalising institution (and education system) among the members of the Pinetree staff. Their discourses and practices emically position educators into two broad categories: "permanent" (funcionaris) vs. "non-permanent (interins)". The civil servants have the possibility of freely deciding whether or not to join the PEP, which they mostly construct as the embodiment of a morally superior professional stance and the possibility of activating themselves. By contrast, the non-permanent teachers, with a less stable position, need to accommodate themselves to the demands of the institution and offer their skills and expertise so that the school fulfils the requirements for participation demanded by PEP. The fact of the matter is that, without the non-permanent teachers, there would not be enough courses taught in English at Pinetree Secondary (at least some CLIL activities per year of compulsory education) for the school to be allowed to join the scheme. Nonpermanent teachers are forced to become flexible, "happily" to embrace new teaching methodologies. If they do, given the increasing autonomy of schools and head teachers to define teacher and school profiles, they will probably not be invited to stay at the 
school the following year. It is therefore in their interests to accept. As a counterpart, Juan's narrative reports how his enforced flexibility entails devoting more time and effort to his classes for no guaranteed future reward, ${ }^{12}$ but it is also a professional opportunity for him. This ambivalence, together with concerns of social equality, shapes his discourse and practice.

The critical sociolinguistic approach to CLIL adopted in this paper has allowed us to throw light on the complex material conditions of situated CLIL implementation, and has made visible the hidden efforts of many self-sacrificing non-permanent teachers who, in the Catalan context, represent $32.13 \%$ of the workforce $(23,406$ teachers) in the state education system, according to data released by the trade union USTEC (2016). With only 300 state teaching posts opening in 2016-17 the situation will not change for a few years to come. What we can learn from the success of PEP in Pinetree School is that it is predicated on the institutional exploitation of already existing inequalities, and on the basis of an increasingly precarious teaching profession that demands ever greater flexibility from its workforce. We believe policy makers should pay more attention to these complexities and understand how they might impact the continuity and sustainability of language policies such as CLIL over time. We also consider it necessary that the contribution to CLIL of temporary educators should be more explicitly recognised both symbolically and practically in the form of easier access to stable teaching positions.

\footnotetext{
${ }^{12}$ Teaching experience and other merits add up to the mark obtained in the official examination for permanent posts. Applicants are ranked according to their final score. Participation in CLIL schemes such as PEP is currently not allocated specific points, but considered within the general category "teaching innovation schemes".
} 


\section{Appendix}

\section{Symbols used in transcripts}

PART: participant name

(.) short pause (0.5 seconds)

(:) long pause $(0.5-1.5$ seconds $)$

( ) incomprehensible fragment

AA loud talking

- self interruption

= continuation of utterance after overlapping

$\backslash$ descending intonation

/ rising intonation

A:: lengthening of vowel or consonant

(( )) slowly

sound

[ ] turn overlapping with similarly marked

turn

\section{References}

Agustín-Llach, M.P. \& Canga Alonso, A. (2016). Vocabulary growth in young CLIL and traditional EFL learners: Evidence from research and implications for education. International Journal of Applied Linguistics, 26(2), 211-227.

Banegas, D.L. (2012). CLIL teacher development: Challenges and experiences. Latin American Journal of Content \& Language Integrated Learning, 5(1), 46-56.

Beadle, S., Humburg, M., Smith, R., \& Vale, P. (2015). Study on Foreign Language Proficiency and Employability. Brussels: European Commission.

Block, D., Gray, J., \& Holborow, M. (2012). Introduction. In D. Block, J. Gray, \& M. Holborow (Eds.), Neoliberalism and Applied Linguistics (pp. 1-13). London: Routledge.

Borg, S. (2011). The impact of in-service education on language teachers' beliefs. System, 39, 370-380.

Bovellan, E. (2014). Teachers' beliefs about learning and language as reflected in their views of teaching materials for content and language integrated learning (CLIL). Jyväskylä Studies in Humanities 231. Available from: 
https://jyx.jyu.fi/dspace/bitstream/handle/123456789/44277/978-951-39-58091_vaitos20092014.pdf?sequence=1.

Bros Pérez, G. (2015). Content and Language Integrated Learning in the Catalanspeaking territories of Spain. European Journal of Language Policy, 7(1), 43-62.

Bruton, A. (2013). CLIL: Some of the reasons why... and why not. System, 41(3), 587897.

Cenoz, J., Genesee, F., \& Gorter, D. (2014). Critical analysis of CLIL: Taking stock and looking forward. Applied Linguistics, 35(3), 243-262.

Codó, E. \& Patiño-Santos, A. (2014) Beyond Language: Class, Social Categorisation and Academic Achievement in a Catalan High School. Linguistics and Education $25,51-63$.

Costa, F. \& Pladevall-Ballester, E. (forthcoming) Language teachers' perspectives on the CLIL experience in Catalan and Lombard secondary schools. Linguistics and Education.

Coyle, D. (2007) Content and language integrated learning: Towards a connected research agenda for CLIL pedagogies. International Journal of Bilingual Education and Bilingualism, 10(5), 543-562.

Coyle, D., Hood, P., \& Marsh, D. (2010). CLIL: Content and Language Integrated Learning. Cambridge: Cambridge University Press.

Dalton-Puffer, C. (2008). Outcomes and processes in content and language integrated learning (CLIL): Current research from Europe. In Delanoy, W. \& L. Volkmann (Eds.) Future Perspectives for English Language Teaching (pp. 139-157). Heildelberg: Carl Winter.

Dalton-Puffer, C., Nikula, T., \& Smith, U. (Eds.) (2010). Language Use and Language Learning in CLIL Classrooms. Amsterdam: John Benjamins. 
Doiz, A., Lasagabaster, D., \& Sierra, J. M. (2014). CLIL and motivation: The effect of individual and contextual variables. The Language Learning Journal, 42(2), 209224.

Ellis, R. (2003) Task-based Language Learning and Teaching. Oxford: Oxford University Press.

Escobar, C. \& Evnitskaya, N. (2014). 'Do you know Actimel?' The adaptive nature of dialogic teacher-led discussions in the CLIL science classroom: a case study. The Language Learning Journal, 42(2), 165-180.

European Commission (2003). Promoting Language Learning and Linguistic Diversity: An Action Plan 2004-2006. Brussels: European Unit.

Foucault, M. (1991). “Governmentality.” In G. Burchell, C. Gordon \& P. Miller (Eds.), The Foucault Effect: Studies on Governmentality (pp. 87-104). Chicago: University of Chicago Press.

Fraser, N. (2003). "From Discipline to Flexibilization: Rereading Foucault in the Shadow of Globalisation.” Constellations, 10 (2): 160-71.

Gao, S., \& Park, J. S. Y. (2015). Space and language learning under the neoliberal economy. L2 Journal, 7(3), 78-96.

Garrido, M.R. \& Codó, E. (2017) Deskilling and Delanguaging African Migrants in Barcelona: Pathways of Labor Market Incorporation and the Value of Global English. Globalisation, Societies and Education 15 (1), 29-49.

Gee, J. P., Hull, G., \& Lankshear, C. (1996). The New Work Order: Behind the Language of the New Capitalism. Boulder, CO: Westview Press.

Heller, M. (2006). Linguistic Minorities and Modernity: A Sociolinguistic Ethnography (2nd edition). London: Continuum.

Heras, A. \& Lasagabaster, D. (2015). The impact of CLIL on affective factors and 
vocabulary learning. Language Teaching Research, 19, 70-88.

Hüttner, J., Dalton-Puffer, C., \& Smit, U. (2013). The power of beliefs: Lay theories and their influence on the implementation of CLIL programmes. International Journal of Bilingual Education and Bilingualism, 16(3), 267-284.

Jakonen, T. \& Morton, T. (2013). Epistemic search sequences in peer interaction in a content-based language classroom. Applied Linguistics, 36(1), 73-94

Lin, A. M. (2015). Conceptualising the potential role of L1 in CLIL. Language, Culture and Curriculum, 28(1), 74-89.

Lin, A. M. (2016) Language Across the Curriculum \& CLIL in English as an Additional Language (EAL) Contexts: Theory and Practice. Singapore: Springer.

Llinares, A, Morton, T., \& Whitakker, R. (2012). The Roles of Languages in CLIL. Cambridge: Cambridge University Press.

Lorenzo Galés, M. N., \& Piquer Vives, I. (2013). Report and evaluation of the development of CLIL programmes in Catalonia. Temps d'Educació, 45, 143-180.

Lorenzo, F., Casal, S., Moore, P. (2010). The effects of content and language integrated learning in European education: Key findings from the Andalusian sections evaluation project. Applied Linguistics, 31, 418-442.

Marsh, D. (Ed.) (2002). CLIL/EMILE. The European Dimension. Actions, Trends, and Foresight Potential. Jyväskylä: UniCOM, Continuing Education Centre.

Martín Rojo, L. (2013). (De)capitalising students through linguistic practices: A compararative analysis of new educational programmes in the global era. In A. Duchêne, M. Moyer, \& C. Roberts (Eds.), Language, Migration and Social Inequalities: A Critical Perspective on Institutions and Work (pp. 118-146). Bristol: Multilingual Matters.

Merisuo-Storm, T. (2007) Pupils' attitudes towards foreing-language learning and the 
development of literacy skills in bilingual education. Teaching Teacher Education, $23,226-235$.

Morton, T. (2016). Being a language teacher in the content classroom: Teacher identity and content and language integrated learning (CLIL). In S. Preece (Ed.), The Routledge Handbook of Language and Identity (pp. 382-395). London: Routledge.

Muñoz, C. (2007) CLIL: Some thoughts on its psycholinguistic principles. Revista Española de Lingüística Aplicada. Special issue 1 "Models and practice in CLIL", $17-26$.

Navés, T., \& Victori, M. (2010). CLIL in Catalonia: An overview of research studies. In D. Lasagabaster \& Y. Ruiz de Zarobe (Eds.), CLIL in Spain: Implementation, Results and Teacher Training (pp. 30-53). Newcastle: Cambridge Scholars.

Nikula, T. (2010). Effects of CLIL on a teacher's classroom language use. In C. DaltonPuffer, T. Nikula \& U. Smit (Eds.) Language Use and Language Learning in CLIL Classrooms (pp.105-123). Amsterdam: John Benjamins.

Pérez-Milans, M. (2013). Urban Schools and English Language Education in Late Modern China: A Critical Sociolinguistic Ethnography. London: Routledge.

Pérez-Milans, M. (2015). Language education policy in late modernity:

(Socio)linguistic ethnographies in the European Union. Language Policy, 14 (2), 99-108.

Pérez-Milans, M., \& Patiño-Santos, A. (2014). Language education and institutional change in a Madrid multilingual school. International Journal of Multilingualism, 11(4), 449-470.

Pladevall-Ballester, E. (2015). Exploring primary school CLIL perceptions in Catalonia: Students', teachers' and parents' opinions and expectations. International Journal of Bilingual Education and Bilingualism, 18(1), 45-59. 
Pujolar, J. (2007). Bilingualism and the nation-state in the post-national era. In M Heller (Eds.), Bilingualism: A Social Approach (pp. 71-95). London: Palgrave.

Rampton, B. (1997). Retuning in applied linguistics. International Journal of Applied Linguistics, 7(1), 3-25.

Rampton, B. (2006). Language in Late Modernity: Interaction in an Urban School. Cambridge: Cambridge University Press.

Relaño-Pastor, A. M. (2015). The commodification of English in "Madrid, comunidad bilingüe”: Insights from the CLIL classroom. Language Policy, 14(2), 131-152. Relaño-Pastor, A.M. (2018) Narrative circularity, disputed transformations, and bilingual appropriations at a public school 'somewhere in La Mancha'. International Journal of the Sociology of Language. Special Issue "Storytelling in globalized spaces: a linguistic ethnographic perspective”, A. Patiño-Santos (Ed.).

Robertson, P. \& Adamson, J. (2013) CLIL in Asian Contexts: Emerging Trends. Asian EFL Journal (Special issue), 15 (4), 1-450.

Skinnari, K. \& Bovellan, E. (2016). CLIL teachers' beliefs about integration and their professional roles: Perspectives from a European context. In T. Nikula, E. Dafouz, P. Moore \& U. Smit (Eds). Conceptualising Integration in CLIL and Multilingual Education (pp. 145-170). Bristol: Multilingual Matters.

Tollefson, J. \& Pérez-Milans, M. (in press) Research and Practice in Language Policy and Planning. In J.W. Tollefson \& M. Pérez-Milans (Eds.), The Oxford Handbook of Language Policy and Planning. Oxford: OUP.

Turner, M. (2013). CLIL in Australia: The importance of context. International Journal of Bilingual Education and Bilingualism, 16(4), 395-410.

Urciuoli, B. (2008). Skills and selves in the new workplace. American Ethnologist, $35(2), 211-228$. 
Urciuoli, B., \& LaDousa, C. (2013). Language management/labor. Annual Review of Anthropology, 42, 175-190.

USTEC.STEs (2016) “Inici de curs”. Full informatiu 311. Available from:

http://www.sindicat.net/w/fullinf/full311.pdf.

Van de Craen, P., Ceuleers, E. \& Mondt, K. (2007). Cognitive development and bilingualism in primary schools: Teaching maths in a CLIL environment. In D.

Marsh, \& D. Wolff (Eds.), Diverse Contexts - Converging goals. CLIL in Europe. (pp. 186-200). Frankfurt a.M.: Peter Lang.

Pavón, V. \& Rubio, F. (2010). Teachers' concerns and uncertainties about the introduction of CLIL programmes. Porta Lingarium, 14, 45-58. 